Rev. Int. Contam. Ambie. 36 (3) 775-787, 2020

https://doi.org/10.20937/RICA.53357

\title{
REVIEW
}

\section{MINING APPLICATIONS OF IMMOBILIZED MICROBIAL CELLS IN AN ALGINATE MATRIX: AN OVERVIEW}

Aplicaciones mineras de células microbianas inmovilizadas en matriz de alginato: una visión general

\author{
Ellen C. GIESE
}

Centro de Teconologia Mineral - CETEM, Avenida Pedro Calmon 900, CEP 21941-908, Rio de Janeiro-RJ, Brasil

E-mail: egiese@cetem.gov.br

(Received July 2018; accepted October 2019)

Key words: $\mathrm{Ca}^{2+}$ alginate, cell immobilization, environmental recovery, mining industry

\begin{abstract}
Immobilized microbial cells have been used extensively in various industrial processes. However, immobilized cells have not been used widely for mining industrial applications. Cell immobilization consists of a technique by which microorganisms are confined through physical or chemical interactions in a matrix, or fixed to the surface of the immobilizing agent. In recent years, entrapment of cells within spheres of $\mathrm{Ca}^{2+}$ alginate has become the most widely used technique for immobilizing living cells. This review examines many of the scientific and technical aspects involved in using $\mathrm{Ca}^{2+}$ alginate immobilized microbial cells in mining activities, with a particular focus on the biohydrometallurgical industrial applications and processes of soil bioremediation in heavy metal contaminated mining areas, environmental recovery of atmospheric emissions containing $\mathrm{H}_{2} \mathrm{~S}$ and treatment of acid mine drainage.
\end{abstract}

Palabras clave: alginato de $\mathrm{Ca}^{2+}$, industria minera, inmovilización celular, recuperación ambiental

\section{RESUMEN}

Las células microbianas inmovilizadas se han utilizado ampliamente en diversos procesos industriales. Sin embargo, no se han usado de manera tan extensa en las aplicaciones para la industria minera. La inmovilización celular consiste en una técnica mediante la cual los microorganismos se confinan a través de interacciones físicas o químicas en una matriz, o se fijan a la superficie del agente inmovilizador. En los últimos años, el atrapamiento de las células dentro de esferas de alginato de $\mathrm{Ca}^{2+}$ se ha convertido en la técnica más utilizada para inmovilizar las células vivas. Esta revisión examina muchos de los aspectos científicos y técnicos que abarca el uso de células microbianas inmovilizadas con alginato de $\mathrm{Ca}^{2+}$ en aplicaciones en las actividades mineras, con un enfoque particular en las industriales biohidrometalúrgicas y en los procesos de biorremediación de suelos en áreas mineras contaminadas con metales pesados, recuperación ambiental de emisiones atmosféricas que contienen $\mathrm{H}_{2} \mathrm{~S}$ y tratamiento del drenaje ácido de minas. 


\section{INTRODUCTION}

Immobilization techniques have been used in a variety of scientific and industrial applications. This technology is a general term to describe many different forms of microbial cell attachment or entrapment, presenting advantages over processes using free cells mainly in bioprocesses operated in bioreactors (Bergmaier et al. 2005).

Besides the advantages that the use of immobilized microbial cells confers to the fermentative processes, e.g., use of a flow system with multiple circulation of the substrate; removal of reaction products; biomass separation in upstream processess (Covizzi et al. 2007); immobilized cells can be also used as catalysts in situ, e.g., for biodegradation of xenobiotic compounds in soils (Usha et al. 2010) or for the treatment of textile effluents under dye biosorption reactions (Mitter and Corso 2013). Immobilization of microbial cells on a suitable support can simplify the wastewater treatment as the entrapment of living cells increases the retention time of cells on contaminated water (Kumar and Raju 2008).

These characteristics are very promising for the development of new technologies in industrial areas that depend on large-scale processes with greater demands than the fermentative processes, as the case of the mining industry. There is growing awareness of the geochemical significance of microbes among researchers in geology, mineralogy and geochemistry, which has been causing the microorganisms to be exploited for the development of new technologies in these areas of interest (Gaad 2010).

The wastes generated by the mining industry contain high concentrations of highly toxic and non biodegradable metals and metalloids which can be mobilized, resulting in leaching into groundwater and surface water. Sustainable mining wastewater treatment technologies have been emerged and the technical applicability, cost-effectiveness and plant simplicity from biosorption process are the key factors that have been discussed (Pinto et al. 2011, Agbesi et al. 2017). These metals must be removed from the polluted streams in order to meet increasingly stringent environmental quality standards as also as a way of reusing them within the new concepts of circular economy.

Cell immobilization using an alginate matrix is very versatile and presents different applications, allowing the use of live or inactivated cells in bioreactors (Kureel et al. 2017), enabling innovative applications in different areas. Bioreactors operated using microbial cells immobilized on $\mathrm{Ca}^{2+}$ alginate beads has been extensively described in the literature in fermentation processes, e.g., for production of acids (Yoo et al. 1996), carotenoids (Garbayo et al. 2003), sweeteners (Kawaguti and Sato 2011), fermented beverages (García-Martínez et al. 2015) and ethanol (Bangrak et al. 2011).

Encapsulation of microbial cells in a gel-matrix has been emerged as a successful and useful method for commercial aplications. The alginate matrix has unique properties that make it a product of great commercial importance for its ability to gel and thicken solutions, as well as its biotechnological potential as a support for the immobilization of enzymes and cells (Smidsrød and Skjåk-Braek 1990, Giese 2015).

$\mathrm{Ca}^{2+}$ alginate immobilized biocatalysts have been outstanding for presenting applications in other areas with emerging potential. The use of immobilized cells has been investigated as an alternate technology for some processes that involve the mining industries (Martínez and Parada 2013) as well as related processes for the recovery of degraded mining areas (Sinha and Khare 2012, Bayat et al. 2015).

For example, the use of immobilized cells in bioleaching (Martínez and Parada 2013), heavy metals (Sinha and Khare 2012, Mishra 2013), mercury (Sinha and Khare 2012) and rare-earth elements biosorption (Coimbra et al. 2017, Corrêa et al. 2017, Coimbra et al. 2019), acid mine drainage (Long et al. 2004), bioremediation (Zommere and Nikolajeva 2017), and $\mathrm{H}_{2} \mathrm{~S}$ removal (Chung et al. 2010) have all been examined. However, most of these investigations were perfomed at laboratorial level, and applications of immobilized cells in mining activities in the open environment and industrial scale have yet to be realized.

This paper consists in an overview about immobilization of microbial cells in $\mathrm{Ca}^{2+}$ an alginate matrix for applications in the mining industry, with emphasis on applying this technology for heap bioleaching proccesses and for in situ recovery of environments contaminated by mining activities.

\section{$\mathrm{Ca}^{2+}$ alginate matrix}

Alginate is a linear polysaccharide composed of units of mannuronic acid bound by glycosidic bonds of $\beta$-D- $(1 \rightarrow 4)$ type, and also, by units of guluronic acid, linked by $\alpha-\mathrm{D}-(1 \rightarrow 4)$ bonds. These polysaccharides were first isolated from brown algae belonging to the genera Laminaria and Macrocystis, and are also produced by bacteria of the genera Pseudomonas and Azotobacter, being that the proportion of $\beta$-Dmannurate and $\alpha$-D-guluronate units depends on the alginate origin (Guo et al. 2006). 
The proportion between these monosaccharides is important to the mechanical properties of the alginate gel spheres. The degree of polymerization of alginate chains also exerts a determinant influence on their ability to form gel, which depends on the presence of divalent ions such as $\mathrm{Ca}^{2+}$ or $\mathrm{Mg}^{2+}$ and residues of D-guluronic acid (Lee and Mooney 2012).

Alginate particles can be obtained by different methods, including emulsification and, especially, the drip technique of sodium alginate solutions containing microbial cells in calcium chloride solution $\left(\mathrm{CaCl}_{2}\right)$. In the latter case, the high concentration of the polymer matrix favors the formation of compact beads with uniform surfaces, which have high mechanical resistance and stability both during the fermentation process and during the storage time (Vos et al. 2009).

$\mathrm{Ca}^{2+}$ alginate beads formation occurs through a reaction called ionic gelling (Skjåk-Bræk et al. 1989). To do so, a suspension of microbial cells in $\mathrm{Na}^{+}$ alginate solution is dripped in an ionic solution of suitable concentration, usually $\mathrm{CaCl}_{2}$ to form the gel of different porosity according to the pre-optimized conditions (Blandino et al. 1999, Covizzi et al. 2007), as illustrated in figure $\mathbf{1}$.

Binding $\mathrm{Ca}^{2+}$ ions to guluronate residues results in the formation of consistent and insoluble alginate gel beads with controllable swelling properties, low toxicity, size and defined pore distribution. Physicalchemical characteristics of immobilized biocatalysts will depend on the flow velocity, density of the polymer solution and concentration of ionic solution in which the gel will be formed (Wang et al. 2005).

Gelling properties of alginate come from linkages between divalent cations and guluronate residues, which favor the formation of a thermostable gel. The degree of substitution of $\mathrm{Ca}^{2+}$ ions depends on the contact time between the spheres formed and the ionic solution, as well as the acidity of this solution. For example, the substitution is maximal at $\mathrm{pH}$ close to neutrality at the contact time of 1 hour in the presence of $\mathrm{Ca}^{2+}$ ions (Fundueanu et al. 1999).

Alginate-based products are popular in many industries, including food production and in pharmaceutical and biomedical applications (Yeung and Kennedy 2019). $\mathrm{Ca}^{2+}$ alginate beads have been used successfully in fermentative processes in the food industry, e.g., as a carrier for enzymes for winemaking (Martín et al. 2019) and as adsorbent of contaminants in juice fruits (Farbo et al. 2016). This gelly matrix have been also employed in wastewater treatment processes (Kube et al. 2019).

Immobilized microorganisms in $\mathrm{Ca}^{2+}$ alginate beads have been extensively used in food processes (Souza et al. 2009), bioetanol production (Santos et al. 2018) and bioremediation (Khalid et al. 2018).

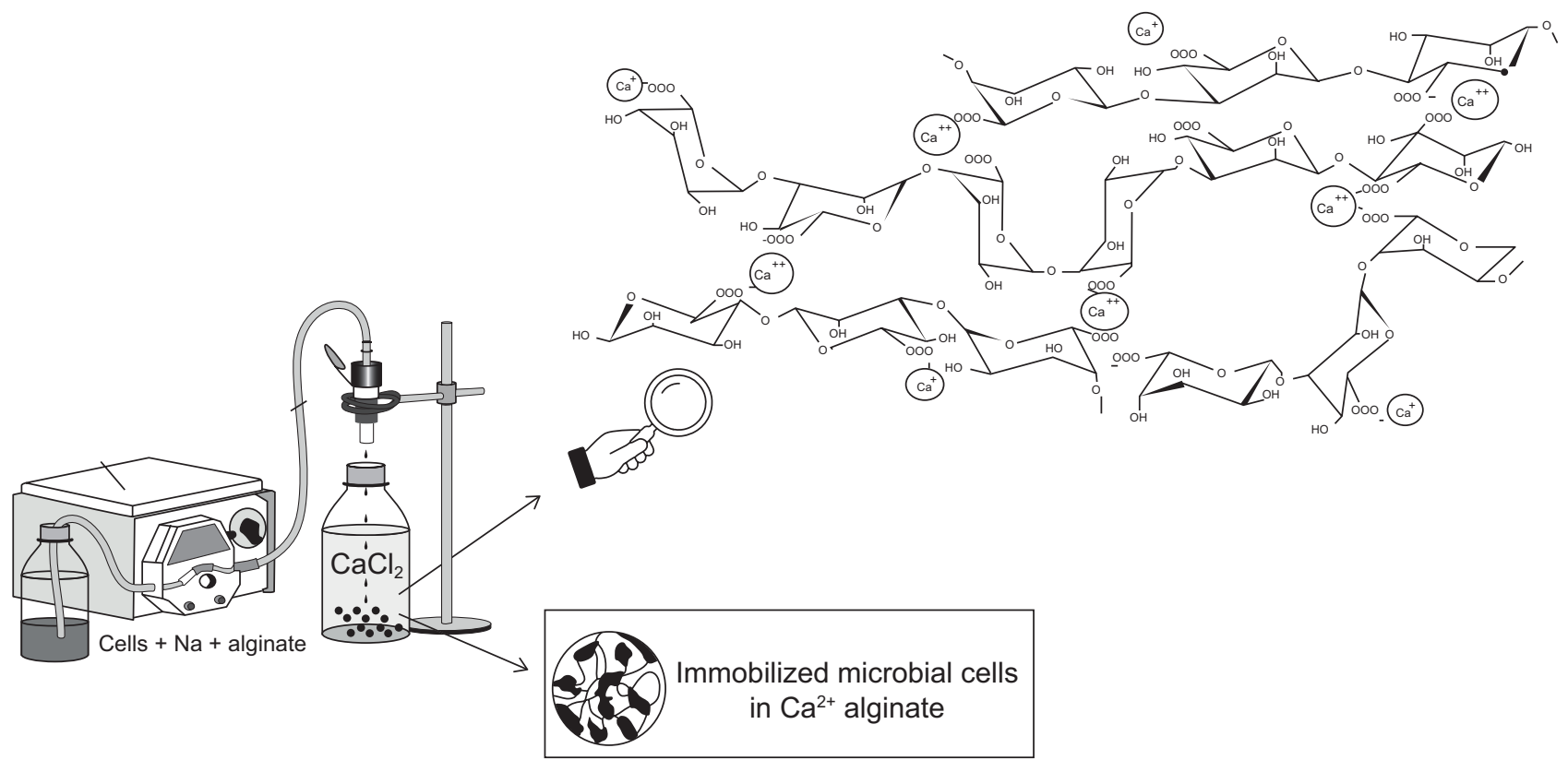

Fig 1. Schematic illustration for the preparation of $\mathrm{Ca}^{2+}$ alginate beads containing immobilized cells. In detail, the $\mathrm{Na}^{+}$monovalent ion substitution by $\mathrm{Ca}^{2+}$ divalent ion in alginate-matrix. 
The use of biocatalysts in mining activities has been little described in the literature and deserves attention due to the minimized costs and lower environmental impact.

\section{BIOLEACHING PROCESSES}

Bioleaching is a hydrometallurgical process of mineral sulfides dissolution by the action of a group of microorganisms capable of producing oxidizing agents (Schippers 2007, Musa et al. 2015, Giese 2017). In recent years, bioleaching techniques were applied successfully and commercially for extracting copper and gold from various samples, such as sludge (Pathak et al. 2009), flyashes (Park and Liang 2019), sediments (Gentina and Acevedo 2016), soils (Abdullah et al. 2017), batteries (Bahaloo-Horeh et al. 2016), etc.

Different hydrometallurgicall technologies have been used to the extraction of valuable metals, however, recovery of minerals containing sulfide, are based on the activities of chemolithotrophic bacteria and fungi, as they convert insoluble metal sulfides residues into soluble metal sulfates (Okoh et al. 2018). The gram-negative bacterium Acidithiobacillus ferrooxidans was the first microbial species to be used in the bioleaching processes of copper mineral sulfides, and is currently used in the solubilization of different metals. This bacteria is acidophilic, aerobic, mesophilic, autotrophic and chemotrophic, being able to obtain energy from the oxidation of $\mathrm{Fe}^{2+}$ ions to $\mathrm{Fe}^{3+}$ as well as reduced sulfur compounds (Schippers 2004).

Microorganisms are able to mobilize metals through the formation of organic and inorganic acids, excretion of complexing agents and, more common, through oxidation and reduction reactions (Mishra et al. 2005). In general, bioleaching reactions occurs in two different ways, as described below (Jafari et al. 2018, Giese 2019):

a) thiosulfate mechanism $\left(\mathrm{FeS}_{2}, \mathrm{MoS}_{2}\right.$, and $\left.\mathrm{WS}_{2}\right)$, where $\mathrm{Fe}^{3+}$ ions oxides metal sulfides generating thiosulfate as intermediary and main end-product:

$\mathrm{FeS}_{2}+6 \mathrm{Fe}^{3+}+3 \mathrm{H}_{2} \mathrm{O} \rightarrow \mathrm{S}_{2} \mathrm{O}_{3}^{-2}+7 \mathrm{Fe}^{2+}+6 \mathrm{H}^{+}$

$\mathrm{S}_{2} \mathrm{O}_{3}^{-2}+8 \mathrm{Fe}^{3+}+5 \mathrm{H}_{2} \mathrm{O} \rightarrow 2 \mathrm{SO}_{4}^{-2}+8 \mathrm{Fe}^{2+}+10 \mathrm{H}^{+}$

b) polysulfide mechanism $\left(\mathrm{ZnS}, \mathrm{CuFeS}_{2}\right.$, and $\left.\mathrm{PbS}\right)$, where metal solubilization results from a com- bined attack by $\mathrm{Fe}^{3+}$ ions and protons, and the elemental sulfur $\left(\mathrm{S}_{0}\right)$ is the main intermediate:

$\mathrm{MS}+\mathrm{Fe}^{3+}+\mathrm{H}^{+} \rightarrow \mathrm{M}^{2+}+0.5 \mathrm{H}_{2} \mathrm{~S}_{\mathrm{n}}+\mathrm{Fe}^{2+}(\mathrm{n} \geq 2)$

$0.5 \mathrm{H}_{2} \mathrm{~S}_{\mathrm{n}}+\mathrm{Fe}^{3+} \rightarrow 0.125 \mathrm{~S}_{8}+\mathrm{Fe}^{2+}+\mathrm{H}^{+}$

$0.125 \mathrm{~S}_{8}+1.5 \mathrm{O}_{2}+\mathrm{H}_{2} \mathrm{O} \rightarrow \mathrm{SO}_{4}^{2-}+2 \mathrm{H}^{+}$

Microorganisms involved in the bioleaching processes are usually adhered to the surface of the mineral sulphides (sessile cells), while a part of the microbial population can be found dispersed in solution (plankton cells). Bacterial adhesion to the mineral surface seems to enhance bioleaching of ore sulfides, where the presence of extracellular polymeric substances mediates the contact between the mineral surface and the microbial cells, followed by the formation of a biofilm covering the mineral surface with bacterial cells embedded in a continuous layer of EPS (Giese 2019). The bacterial biofilm formed as a consequence of cellular adhesion is able to complex the $\mathrm{Fe}^{3+}$ ions and potentiate the oxidative reactions on the surface of the mineral sulfide, promoting their dissolution (Latorre et al. 2016).

Thus, the presence of a higher microbial cells concentration in the bioleaching system is an important factor to be considered for the efficiency of this biohydrometallurgical process (Hedrich et al. 2016). In general, microbial cells are inoculated through a process of incorporation of microbial cells to the ore sample in rotary tanks to favor agglomeration (Rawlings 2013).

Use of microbial cells immobilized as inoculum is an alternative to ensuring a more uniform adhesion of the bioleaching bacteria to the ore, since the support used in the immobilization should ensure that the bacterial cells are leached and colonize the ore heap completely. Cell immobilization also contributes to increase microbial cells tolerance to higher concentrations of solubilized heavy metals during the microbial leaching process (Martínez and Parada 2013).

A. ferrooxidans cells immobilization have been describe also to improve the rate of $\mathrm{Fe}^{2+}$ oxidation. A. ferrooxidans immobilized can also keep higher cellular metabolic activity and achieve high cell concentrations inside reactors and heaps (Gómez et al. 2000). Giese and Vaz (2015) observed that $A$. ferrooxidans immobilized cells in glass beads as 
inoculum of primary nickel ore leaching showed the same efficiency as the conventional innoculum agglomeration method for columns tests. Nie et al. (2015) observed an average ferrous iron oxidation rate of $0.54 \mathrm{~g} /(\mathrm{L} . \mathrm{h})$ and a ferrous iron oxidation ratio of $96.90 \%$ in copper extraction from waste printed circuit boards via immobilization of $A$. ferrooxidans on cotton gauze.

A. ferrooxidans cells were also immobilized in a matrix formed by PVA and $\mathrm{Na}^{+}$alginate (Yujian et al. 2006). A technique for obtainment of gel-matrix using $\mathrm{Ca}\left(\mathrm{NO}_{3}\right)_{2}$ was applied and the PVA-calcium nitrate beads showed a $\mathrm{Fe}^{3+}$ oxidation rate of $4.6 \mathrm{~g} /$ (L.h) in batch cultures.

Commercial immobilized microbial cells in $\mathrm{Ca}^{2+}$ alginate matrix for bioleaching applications was first described as "seeds" (BioSigma Bioleaching Seeds, BBS), which contain immobilized cells of Acidiphilium spp., Leptospirillum spp., Sulfobacillus spp., Acidithiobacillus spp., A. ferrooxidans, A. thiooxidans, Acidianus spp., Ferroplasma spp., Metallosphaera spp., Sulfolobus spp. and Thermoplasma spp. The matrix used for these bacteria cells immobilization is composed by $\mathrm{Ca}^{2+}$ alginate, $\mathrm{Fe}^{2+}$ ions (10-40 \%) and $\mathrm{Fe}^{3+}$ ions $(60-90 \%)$, which is capable of retaining $10^{3} \mathrm{~g}$ microbial cells $/ \mathrm{g}$ of immobilized material (Martínez and Parada 2015).

Bioleaching process is actually considered as a high potential green technology, due to the minimal damage it causes to the environment and to its contribution to reduce the amount of greenhouse gases in our atmosphere. Moreover bioleaching has cost benefits especially when compared with the largescale capital investment required for a chemical treatment plant. More recently, bioleaching has been considered as a bioremediation tool for cleaning up heavy metal pollution and hazardous industrial waste such as fly ash, slag, and slag and filter dust (Okoh et al. 2018). However, the use of microorganisms immobilized in sodium alginate for this purpose has not been described in the literature.

\section{BIOSORPTION FOR METAL BIOREMEDIATION IN CONTAMINATED MINING AREAS}

Mining activities have a considerable impact on the environment, not only by soil profile and structure disruption as well as by metal deposition and accumulation in soil, which have negative consequences on human health and on the environment (García and Álvarez 2008). Any mining industrial activity involves environmental risk whether by producing contaminant liquid effluents or solid residues containing heavy metals, and this contamination is generated by mining activities such as excavation, ore transference, smelting and refining, which discharges large amounts of spoils, effluents, wastewater and dust in the environment (Vieira and Stefenon 2017).

Heavy metals most frequently found at contaminated sites are lead, chromium, arsenic, zinc, cadmium, mercury, nickel and copper; and it is necessary to use bioremediation technologies in situ, which requires combinated biotechnological and microbiological techniques (García and Álvarez 2008, Vieira and Stefenon 2017). Biosorption is the most common strategy employed in bioremediation of contaminated soil, and concerns the application of microbes (bacteria or fungi) as the main tool. In this process, a passive uptake of metals and other pollutant compounds occurs by biological materials as dead microbial cells in free or immobilized form, reversible recovering contaminant elements from soil by functional groups that are present on the surface of biomass (Tapia et al. 2011, Fomina and Gadd 2014, Vieira and Stefenon 2017).

Bioremediation refers to the use of biological processes for the clean-up of contaminated land usually involving the detoxification of hazardous substances by microbial species. In general, a considerable number of microorganisms are able to survive in the most extreme environmental conditions, including the soil of mining areas with high concentration of heavy metals (Singh and Tripathi 2007). In this aspect, the use of immobilized microbial cells has been studied and evaluated for application in metal contaminated soils from mining activity.

Microbial processes for removal of recalcitrant compounds and heavy metals employ live, nonliving cells or biopolymers as biosorbents (Chojnacka 2010). Lin and Lin (2005) have studied soil leaching and $\mathrm{Cd}^{2+}$ adsorption conditions for obtainment of a biosorption process for removal of this heavy metal from contaminated soil. For this purpose, the authors evaluated the yeast $\mathrm{Sac}$ charomycetes pombe immobilized in chitosan and polyvinylalcohol (PVAL) added to alginate $(10 \mathrm{wt}$. $\%)$. Results for soil leaching indicated high $\mathrm{Cd}^{2+}$ adsorption yields (up to $95 \%$ ) in 30 min as well as the possibility of immobilized yeast bead reuse was feasible.

Free and immobilized forms of a yeast strain, Candida krusei, immobilized in $\mathrm{Ca}^{2+}$ alginate, were evaluated for their ability to remove $\mathrm{Cu}^{2+}$ ions from aqueous solution. Infrared spectroscopy showed 
that the primary biosorption sites on the biosorbents were carboxylate $\left(\mathrm{COO}^{-}\right)$groups (Luk et al. 2017). Kumar and Raju (2008) have also demonstrated that immobilized forms of Halobacterium cutirubrum were more favorable to $\mathrm{Cu}^{2+}, \mathrm{Cd}^{2+}, \mathrm{Ba}^{2+}, \mathrm{Mg}^{2+}, \mathrm{Zn}^{2+}$ and $\mathrm{Pb}^{2+}$ ions removal from aqueous solution than bacterium free cells. Similar results were obtained for a comparison between free and PVAL- $\mathrm{Ca}^{2+}$ alginate immobilized cells from Aspergillus niger fungi (Tsekova et al. 2010). Alginate is considered a natural organic carrier that presents many functional groups to stabilize biocatalysts (Smidsrød and SkjåkBraek 1990). Immobilized microorganisms have demonstrated higher decontamination efficiency than free cells in bioremediation processes (Dzionek et al. 2016).

In free cells, the interaction between heavy metal ions and microbial biomass occurs through the presence of active sites on the cell wall such as amino $(\mathrm{N}-\mathrm{H})$ and carboxylate $\left(\mathrm{COO}^{-}\right)$groups derived mainly from chitin (poly-N-acetylglucosamine) and glucan (poly-D-glucose) constituents. In microbial$\mathrm{Ca}^{2+}$ alginate immobilized form, the carboxylate groups are prominent once alginic acid is structurally similar to D-mannose and its C-6 position is a carboxylate group instead of a hydroxyl group (Kumar and Raju 2008, Piotrowska and Masek 2015, Kumari et al. 2017).

However, some studies demonstrated that Chryseomonas luteola bacteria immobilized in alginate bead were capable of adsorb $\mathrm{Cd}^{2+}, \mathrm{Co}^{2+}, \mathrm{Ni}^{2+}$ and $\mathrm{Cu}^{2+}$ ions mediated by its extracellular polymeric substances production despite presence of active groups in the cell wall (Ozdemir et al. 2005a,b). Acidophilic bacteria as Acidiphillium sp. have been also described by reversible biosorption of $\mathrm{Fe}^{2+}$ ions as $\mathrm{FeC}_{2} \mathrm{O}_{4}$ compounds through interactions with carboxylate groups present in its produced exopolymers (Tapia et al. 2016).

These findings can be explained by the biosorption capacity of high molecular weight microbial polymers mainly composed by proteins, polysaccharides, uronic acids, humic substances and lipids. The anionic nature of these substances makes them efficient to effectively sequester positively charged heavy metal ions, which are easily absorbed by functional groups and non-carbohydrate substituent like acetamido, amine, sulfhydral, carboxyl, phosphodiester (techoic acid), phosphate and hydroxyl groups (Gupta and Diwan 2017).

In addition, some microorganisms produce exopolysaccharides (EPS) as a requirement of biofilm architecture and as a mechanism to heavy metal resistance. However, in another aspect, secreted EPS can mobilize metals in soil (Nocelli et al. 2016, Hindersah et al. 2017). This commonly happens to rhizosphere-inhabitant species as Azotobacter. These species have been described by uptake of $\mathrm{Cd}^{2+}$, $\mathrm{CrO}_{4}{ }^{2-}$ and $\mathrm{Hg}^{2+}$ ions, when cultivated on contaminated soils, by metal ion complexation either through functional groups like carboxyl and hydroxyl present in its produced EPS (Joshi and Juwarkar 2009, Rasuolv et al. 2013).

In the case of Chryseomonas luteola, bacterial EPS immobilized in $\mathrm{Ca}^{2+}$ alginate resulted in maximum $\mathrm{Cd}^{2+}$ and $\mathrm{Co}^{2+}$ ion biosorption while alginate bead alone displayed comparatively low metal ion adsorption efficiency (Ozdemir et al. 2005b). The same behavior was reported to Paenibacillus polymyxa EPS immobilized on agar beads for $\mathrm{Pb}^{2+}$ removal (Hassiba et al. 2014).

$\mathrm{Ca}^{2+}$ alginate beads were tested for the removal of $\mathrm{Cu}^{2+}$ and $\mathrm{Cd}^{2+}$ in AMD. In column experiments, $380 \mathrm{~g}$ of $\mathrm{Ca}^{2+}$ alginate beads were packed in a Pyrex column $(2.5 \times 100 \mathrm{~cm})$ and 120 liters of AMD from the Ilgwang mine in Korea were successfully treated $\left(86 \%\right.$ for $\mathrm{Cu}^{2+}$ and $58 \%$ for $\left.\mathrm{Cd}^{2+}\right)$. It was possible to treat more than $300 \mathrm{~mL}$ of AMD using only $1 \mathrm{~g}$ of $\mathrm{Ca}^{2+}$ alginate beads (Park and Lee 2017).

The gold recovery process with the use of elemental mercury $\left(\mathrm{Hg}^{0}\right)$, called amalgamation, has been used extensively in the illegal small-scale gold mining activity since the mid-1980s. These activities produce millions of tons of tailings containing mercury, which are disposed improperly at gold mining sites and agricultural areas (Guiza and Aristizabal 2013).

Once dispersed in the environment, $\mathrm{Hg}^{0}$ undergoes a series of chemical transformations to the consecutively formation of methylmercury $\left(\mathrm{CH}_{3} \mathrm{Hg}\right)$, a highly toxic and recalcitrant compound. When in contact with aquatic environments, it can be incorporated by fish and crustaceans and to reach man by the food chain causing irreversible damages to the nervous system (Domagalski 2001).

One of the ways to reduce the availability of $\mathrm{Hg}^{0}$ in liquid effluents is the use of microbial biomass in biosorption and bioaccumulation processes, as previously described (Sinha and Khare 2012). Use of biocatalysts immobilized in $\mathrm{Ca}^{2+}$ alginate gel for $\mathrm{Hg}^{0}$ bioaccumulation by fungi and bacteria from synthetic effluents has been described in the literature (Kaçar et al. 2002, Sinha et al. 2012). Sinha and Khare (2012) demonstrated that immobilized Enterobacter $\mathrm{sp}$. in $\mathrm{Ca}^{2+}$ alginate promoted the removal of $7.3 \mathrm{mg} \mathrm{Hg}^{0} / \mathrm{L}$ of industrial effluent within $72 \mathrm{~h}$ and $5.0 \mathrm{mg} \mathrm{HgCl} / \mathrm{L}$ 
of synthetic effluent over the same period. A laboratory scale sequential bioreactor for mercury removal was designed by Sinha et al. (2012). Efficiency of mercury removal by Bacillus cereus immobilized on $\mathrm{Ca}^{2+}$ alginate was $104.1 \mathrm{mg} / \mathrm{g}$ on the third day from a synthetic effluent containing $10 \mathrm{mg} \mathrm{Hg}^{2+} / \mathrm{L}$.

Volatization of mercury by immobilized bacterial cells has also been described. Some bacteria are able to enzymatically reduce $\mathrm{Hg}^{2+}$ to the volatile and less toxic form of $\mathrm{Hg}^{0}$, and this is also an alternative for the remediation of contaminated areas. Zeroual et al. (2001) evaluated different substrates for the immobilization of Klebsiella pneumoniae bacteria and its application in $\mathrm{Hg}^{2+}$ volatilization. Among the substrates tested (alginate, polyacrylamide, vermiculite and wood chips), immobilization in $\mathrm{Ca}^{2+}$ alginate presented better efficiency, resulting in rates of volatilization to $\mathrm{Hg}^{0}$ around $89 \%$ in a stable way in continuous operation for 10 days. Immobilized Chrolella cells systems also accumulated more mercury than free cells. Immobilized algae have been used for phosphates, chlorinated hydrocarbons and heavy metals accumulation from wastewater (Wilkinson et al. 1989).

Biosorption technology has been developed as an alternative route for the recovery and separation of rare earth elements, and is seen as a priority and strategic action by several countries demanding these elements. Nowadays, rare earth elements, that describe any of the 15 metallic chemical elements with atomic numbers from 57 to 71 and the chemically similar elements scandium and yttrium, had their global demand increased. The hundreds of uses for rare earth elements, ranging from high tech (lasers, computer memory modules) to energy (batteries, superconductors) applications had also increased the mining of rare earth containing ores and the environmental exposure to these lanthanides (Yantasee et al. 2009). Their ecotoxicity is not fully characterized, however it is known that for alga and bacteria, ecotoxicity increases with increasing rare earth atomic number (González et al. 2015).

Predicting the possibility of increasing the concentration of lanthanides in effluents have been carried out using microbial cells immobilized on $\mathrm{Ca}^{2+}$ alginate for rare earth biosorption processes. $\mathrm{Ca}^{2+}$ alginate immobilized biomass of Bacillus subtilis was applied for La and Sm biosorption studies with high percentual of rare earth removal, 94.4 and 94.9 $\%$, respectively (Coimbra et al. 2017). The kinetic study of La biosorption, in concentrations ranging $10-100 \mathrm{mg} / \mathrm{L}$, showed that $\mathrm{Ca}^{2+}$ alginate microalgal immobilized biosorbents formed by Ankistrodesmus sp. and Golenkinia sp. cells had the same behavior as the free cells, and the kinetic equilibrium was reached quickly in the first few minutes in contact (Corrêa et al. 2017).

\section{HYDROGEN SULPHIDE $\left(\mathrm{H}_{2} \mathrm{~S}\right)$ REMOVAL}

Hydrogen sulfide $\left(\mathrm{H}_{2} \mathrm{~S}\right)$ is among the main pollutants found in the atmosphere and is derived from natural or anthropogenic related microbial activity, including food processing, wastewater treatment, petroleum refining and natural gas, petrochemical industries, tanneries, pulp and paper manufacturing and composting processes (Beauchamp et al. 1984). Once in gaseous form, $\mathrm{H}_{2} \mathrm{~S}$ is easily oxidized to sulfur dioxide $\left(\mathrm{SO}_{2}\right)$ which is then converted to sulfuric acid $\left(\mathrm{H}_{2} \mathrm{SO}_{4}\right)$, which can return to the soil as acid rain (Fig. 2; Maat et al. 2005).

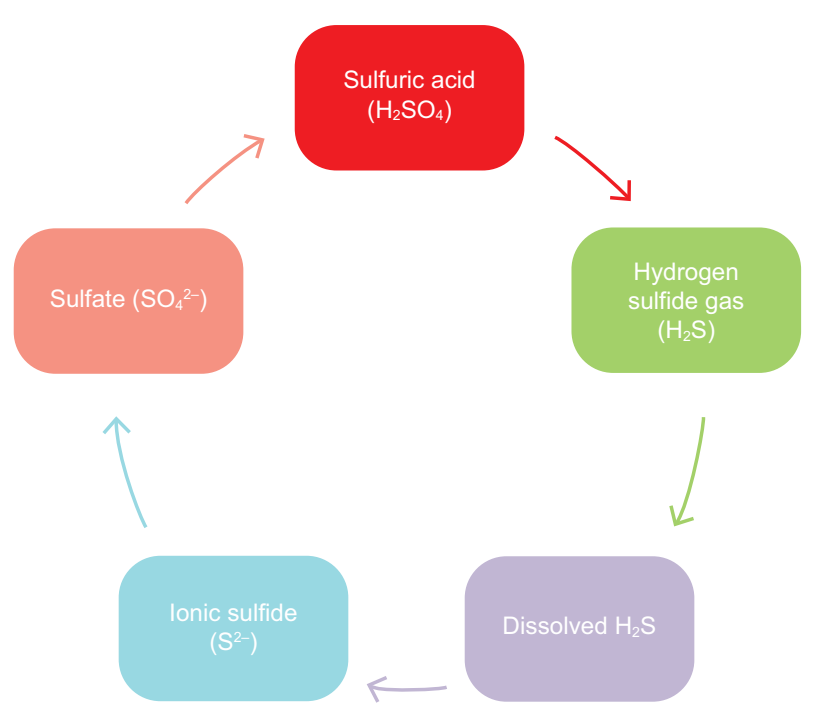

Fig. 2. Schematic illustration for the sulfate cycle.

Generation of $\mathrm{H}_{2} \mathrm{~S}$ in mining activities is common due the presence of naturally occurring sulfatereducing bacteria that reduce the pre-existing sulfate in the mineral composition creating $\mathrm{H}_{2} \mathrm{~S}$. This is the case of coal, for example, that is the world's largest energy source for electricity generation and is mined on six continents. Sulfate contamination of surface and ground water from these mining and processing operations is well recognized and commonly monitored as a primary indicator of coal mining impact to surface water and groundwater, mainly by prominent $\mathrm{H}_{2} \mathrm{~S}$ generation (Simonton and King 2013). 
Microbial $\mathrm{H}_{2} \mathrm{~S}$ removal is based on two stages: 1) absorption stage, in which the $\mathrm{Fe}^{3+}$ ions are converted to ferrous sulfate and the $\mathrm{H}_{2} \mathrm{~S}$ is oxidized to its sulfur form and 2) biological oxidation stage, in which the $\mathrm{Fe}^{2+}$ ions produced in the previous step lead to the formation of $\mathrm{Fe}^{3+}$ again, repeating the cycles. Use of a biological biocatalyst requires mild conditions of temperature and pressure without the need of addition of chemical reagents, reducing operational costs (Malhotra et al. 2002).

Biological treatment of gaseous effluents can be accomplished through the use of bioscrubber, biofilter and biotrickling filters, which are composed of microorganisms capable of degrading and incorporating organic or inorganic pollutants derived from gases. In these processes, bacterial species are used in the immobilized form, mainly for its ability to form biofilms and to fill the columns used for gas filtration. A gas fed batch reactor is composed by a stirred tank type reactor, continuously or intermittently operated in the gas phase (the target flux) and cyclically operated in the liquid phase (nutritive solution) with microorganisms immobilized on different media (Syed et al. 2006, Zhang et al. 2009).

Chung et al. (1996a) evaluated the use of a biofiltration system in the presence of Pseudomonas putida $\mathrm{CH} 11$ cells immobilized on $\mathrm{Ca}^{2+}$ alginate, which showed a $95 \% \mathrm{H}_{2} \mathrm{~S}$ removal efficiency. In another study, a consortium of $P$. putida $\mathrm{CH} 11$ and Arthrobacter oxydans $\mathrm{CH} 8$ immobilized on the same support was used for the degradation of both $\mathrm{H}_{2} \mathrm{~S}$ and $\mathrm{NH}_{3}$ (Chung et al. 2001). Elemental sulfur or sulfate was produced depending on the inlet $\mathrm{H}_{2} \mathrm{~S}$ concentration.

\section{ACID MINE DRAINAGE TREATMENT}

Acid mine drainage (AMD) is a residue from the natural oxidation of sulfide minerals, especially pyrite $\left(\mathrm{FeS}_{2}\right)$, after exposure to moisture and oxygen, in the presence or absence of oxidizing bacteria. This phenomenon can be described by the following reactions, although they occur in a similar way with other sulphides found in mine tailings:

$$
\begin{aligned}
& 2 \mathrm{FeS}_{2}+7 \mathrm{O}_{2}+2 \mathrm{H}_{2} \mathrm{O} \rightarrow 2 \mathrm{Fe}^{2+}+4 \mathrm{SO}_{4}^{2-}+4 \mathrm{H}^{+} \\
& \mathrm{FeS}_{2}+14 \mathrm{Fe}^{3+}+8 \mathrm{H}_{2} \mathrm{O} \rightarrow 15 \mathrm{Fe}^{2+}+2 \mathrm{SO}_{4}^{2-}+16 \mathrm{H}^{+} \\
& \mathrm{FeS}_{2}+14 \mathrm{Fe}^{3+}+8 \mathrm{H}_{2} \mathrm{O} \rightarrow 15 \mathrm{Fe}^{2+}+2 \mathrm{SO}_{4}^{2-}+16 \mathrm{H}^{+}
\end{aligned}
$$

$$
4 \mathrm{Fe}^{2+}+10 \mathrm{H}_{2} \mathrm{O}+\mathrm{O}_{2} \rightarrow 4 \mathrm{Fe}(\mathrm{OH})_{3}+8 \mathrm{H}^{+}
$$

At first, the minerals oxidize spontaneously by oxidation with molecular oxygen (Equation 6) or by indirect oxidation with the $\mathrm{Fe}^{3+}$ ion (Equation 7). The oxidation of $\mathrm{Fe}^{2+}$ ions (Equation 8) occurs at $\mathrm{pH}$ values close to or above 4.5. At higher $\mathrm{pH}$ values, the $\mathrm{Fe}^{2+}$ ion is precipitated as $\mathrm{Fe}(\mathrm{OH})_{3}$ (Equation 4). The low $\mathrm{pH}$ conditions stimulate the reproduction of acidophilic bacteria that catalyze the transformation of $\mathrm{Fe}^{2+}$ to $\mathrm{Fe}^{3+}$ (Equation 9), which establishes a cycle of reactions that favor the total degradation of the ore (Singer and Stumm 1970, Kleinmann et al. 1981).

Sulfuric acid residues formed dissolve metals and metal hydroxides present in the soil, resulting in a toxic effluent composed mainly by arsenic, cadmium, zinc and uranium. This acidic solution generated during the formation of AMD can reach and contaminate nearby water bodies, causing great environmental problems (Johnson 1986, Akcil and Koldas 2006). Due to the oxidative and leaching capacity of the bacteria present in AMD, the metallurgical industry started to use them in the extraction of metals, as in the process of bioleaching described above.

Different biological processes have been described for the AMD treatment, among them the use of anaerobic microorganisms (such as sulfate reducing bacteria - BRS-) (Bai et al. 2013) as well as the use of bioreactors capable of oxidizing ions $\mathrm{Fe}^{2+}$ in continuous mode (Bigham et al. 1996).

A. ferrooxidans bacteria has been used as a biocatalyst to produce $\mathrm{Fe}^{3+}$ ions from $\mathrm{Fe}^{2+}$ in fixed bed reactors. Substrates commonly used to immobilize bacterial cell in these processes are activated charcoal and glass beads, mainly because of the inherent capacity of the bacteria to form biofilms and consequently increase the concentration of microbial cells in the reactor (Schippers 2004, Giese 2017). Zhou et al. (2006) observed an increase in $\mathrm{Fe}^{3+}$ ion productivity of about 4-fold ( $2 \mathrm{~g} /(\mathrm{L} . \mathrm{h})$ ) when operated a continuous-mode bioreactor with immobilized $A$. ferrooxidans cells in activated charcoal.

Use of polymeric matrix entrapment techniques has also been described for the oxidation of $\mathrm{Fe}^{2+}$ ions. Bioavailability of $\mathrm{Fe}^{2+}$ ions in fixed bed bioreactors, both in continuous batch and repeated batch, has been performed with the use of biocatalysts immobilized in polyvinyl alcohol by the PVA-boric acid method (Long et al. 2004) and $\mathrm{Ca}^{2+}$ alginate (Lancy and Tuovinen 1984) or $\mathrm{Ca}^{2+}$ PVA-alginate (Yujian et al. 2006, Yujian et al. 2007). 


\section{CONCLUSIONS}

The use of immobilized biocatalysts, particularly composed by microbial cells, is a viable alternative in economic and operational terms to be used in biotechnological processes. Since it seeks to preserve microbial metabolic activity in an environment with high cell density, it is effective in increasing the yield of the biosorption and bioaccumulation processes involved. Immobilized microbial cells can be applied suscessufuly in processes of bioremediation and effluent treatment, among others. Cellular immobilization using $\mathrm{Ca}^{2+}$ alginate gel as a polymeric matrix has been an important tool in different areas, including the mineral sector, as it presents itself as a low cost support and good stability.

For example, the use of immobilized cells in bioleaching (Martínez and Parada 2013), heavy metals (Mishra 2013), mercury (Sinha and Khare 2012) and rare-earth elements biosorption (Corrêa et al. 2017, Coimbra et al. 2017, Coimbra et al. 2019), acid mine drainage (Long et al. 2004), bioremediation (Zommere and Nikolajeva 2017), and $\mathrm{H}_{2} \mathrm{~S}$ removal (Chung et al. 2010) have all been examined. However, most of these investigations were perfomed at laboratorial level, and applications of immobilized cells in mining activities in the open environment and industrial scale have yet to be realized.

This paper consists in an overview about immobilization of microbial cels in $\mathrm{Ca}^{2+}$ alginate matrix for applications in mineral industry, with emphasis on applying this technology for heap bioleaching proccesses and for in situ recovery of environments contaminated by mining activity.

\section{REFERENCES}

Abdullah J.J., El-Imam A.A., Grretham D., Du C. and Tucker G.A. (2017). The application of fungi for bioleaching of municipal solid wastes for the production of environmental acceptable compost production. J. Environ. Sci. Public Health, 1 (3), 167-194. https:// doi.org.10.26502/jesph.96120016

Acheampong A. and Ansa E.D.O. (2017). Low-cost technologies for mining wastewater treatment mike. Journal of Environmental Science and Engineering B 6 (1), 391-405. https://doi.org.10.17265/21625263/2017.08.001

Akcil A. and Koldas S. (2006). Acid mine drainage (AMD): Causes, treatment and case studies. J. Clean. Prod. 14 (12-14), 1139-1145. https://doi.org.10.1016/j. jclepro.2004.09.006
Bai H., Kang Y., Quan H., Han Y., Sun J. and Feng Y. (2013). Treatment of acid mine drainage by sulfate reducing bacteria with iron in bench scale runs. Bioresour. Technol. 128 (1), 818-822. https://doi. org.10.1016/j.biortech.2012.10.070

Bahaloo-Horeh N., Mousavi S.M., and Shojaosadati S.A. (2016). Bioleaching of valuable metals from spent lithium-ion mobile phone batteries using Aspergillus niger. J. Power Sources 320 (1), 257-266. https://doi. org.10.1016/j.jpowsour.2016.04.104

Bangrak P., Limtong S. and Phisalaphong M. (2011). Continuous ethanol production using immobilized yeast cells entrapped in loof are enforced alginate carriers. Braz. J. Microbiol. 42 (1), 676-684. https://doi.org.10 $.1590 \% 2 F S 1517-838220110002000032$

Bayat Z., Hassanshanian M. and Cappello S. (2015). Immobilization of microbes for bioremediation of crude oil polluted environments: A mini review. Open. Microbiol. 9 (1), 48-54. https://doi.org.10.2174\% 2F1874285801509010048

Beauchamp R.O., Bus J.S., Popp J.A., Boreiko C.J., Andjelkovich D.A. and Leber P. (1984). A critical review of the literature on hydrogen sulfide toxicity. Crit. Rev. Toxicol. 13 (1), 25-97. https://doi. org. 10.3109/10408448409029321

Bergmaier D., Champagne C.P. and Lacroix C. (2005). Growth and exopolysaccharide production during free and immobilized cell chemostat culture of Lactobacillus rhamnosus RW-9595M. J. Appl. Microbiol. 98 (1), 272284. https://doi.org.10.1111/j.1365-2672.2004.02462.x

Bigham J. M., Schwertmann U. and Pfab G. (1996). Influence of $\mathrm{pH}$ on mineral speciation in a bioreactor simulating acid mine drainage. Appl. Geom. 11 (1), 845849. https://doi.org.10.1016/S0883-2927(96)00052-2

Blandino A., Macías M. and Cantero D. (1999). Formation of calcium alginate gel capsules: influence of sodium alginate and $\mathrm{CaCl}_{2}$ concentration on gelation kinetics. J. Biosci. Bioeng. 88 (1), 686-689. https://doi. org.10.1016/s1389-1723(00)87103-0

Chojnacka K. (2010). Biosorption and bioaccumulation - the prospects for practical applications. Environ. Int. 36 (3), 299-307. https://doi.org.10.1016/j.envint.2009.12.001

Chung Y.C., Huang C. and Tseng C.P. (1996). Biodegradation of hydrogen sulfide by a laboratory-scale immobilized Pseudomonas putida CH11 biofilter. Biotechnol. Progress 12 (6), 773-778. https://doi. org.10.1021/bp960058a

Chung Y.C., Huang C. and Tseng C.P. (2001). Biological elimination of $\mathrm{H}_{2} \mathrm{~S}$ and $\mathrm{NH}_{3}$ from waste gases by biofilter packed with immobilized heterotrophic bacteria. Chemosphere 43 (1), 1043-1050. https://doi. org.10.1016/s0045-6535(00)00211-3 
Coimbra N.V., Nascimento M. and Giese E.C. (2017). Avaliação do uso de biomassa bacteriana imobilizada na biossorção de terras-raras leves e médias. Holos 33 (1), 136-146. https://doi.org.10.15628/holos.2017.6445

Coimbra N.V., Goncalves F.S., Nascimento M. and Giese E.C. (2019). Study of adsorption isotherm models on rare earth elements biosorption for separation purposes. Int. J. Mat. Metal. Eng. 13 (1), 200-203.

Corrêa F.N., Luna A.S. and Costa A.C.A. (2017). Kinetics and equilibrium of lanthanum biosorption by free and immobilized microalgal cells. Ads. Sci. Technol. 35 (1), 137-152. https://doi. org. 10.1177/0263617416672667

Covizzi L.G., Giese E.C., Gomes E., Dekker R.F.H. and Silva R. (2007). Imobilização de células microbianas e suas aplicações biotecnológicas. Semina: Tech. Ex. 28 (1), 143-160. https://doi.org.10.5433/1679$0375.2007 \mathrm{v} 28 \mathrm{n} 2 \mathrm{p} 143$

Domagalski J. (2001). Mercury and methylmercury in water and sediment of the Sacramento River Basin, California. Appl. Geochem. 16 (15), 1677-1691. https://doi.org.10.1016/S0883-2927(01)00068-3

Dzionek A., Wojcieszynska D. and Guzik U. (2016). Natural carriers in bioremediation: A review. Electr. J. Biotechnol. 23 (1), 28-36. https://doi.org.10.1016/j. ejbt.2016.07.003

Farbo M.G., Urgeghe P.P., Fiori S., Marceddu S. and Migueli Q. (2016). Adsorption of ochratoxin A from grape juice by yeast cells immobilised in calcium alginate beads. Int. J. Food Microbiol. 217 (1), 29-34. https://doi.org.10.1016/j.ijfoodmicro.2015.10.012

Fomina M., and Gadd G.M. (2014). Biosorption: current perspectives on concept, definition and application. Bioresour. Technol. 160 (1), 3-14. https://doi. org.10.1016/j.biortech.2013.12.102

Fundueanu G., Nastruzzi C., Carpov A., Desbrieres J. and Rinaudo M. (1999). Physico-chemical characterization of Ca-alginate microparticles produced with different methods. Biomaterials 20 (15), 1427-1435. https://doi. org.10.1016/S0142-9612(99)00050-2

Gaad G.M. (2010). Metals, minerals and microbes: geomicrobiology and bioremediation. Microbiol. 156 (Pt 3), 609-643. https://doi.org.10.1099/ mic. 0.037143-0

Garbayo I., Vilchez C., Nava-Saucedo J.E. and Barbotin J.N. (2003). Nitrogen, carbon and light-mediated regulation studies of carotenoid biosynthesis in immobilized mycelia of Gibberella fujikuroi. Enz. Microbial Technol. 33 (5), 629-634. https://doi.org.10.1016/ S0141-0229(03)00182-0

García A.S. and Álvarez E.A. (2008). Soil remediation in mining polluted areas. Macla 10 (1), 76-84.
García-Martínez T., Moreno J., Mauricio J.C. and Peinado R. (2015). Natural sweet wine production by repeated use of yeast cells immobilized on Penicillium chrysogenum. Food Sci. Technol. 61 (1), 503-509. https:// doi.org.10.1016/j.lwt.2014.12.029

Gentina J.C. and Acevedo F. (2016). Copper bioleaching in Chile. Minerals 6 (1), 23. https://doi.org.10.3390/ $\min 6010023$

Giese E.C. (2015). Biocatalisadores imobilizados: prospecção de inovações tecnológicas na última década. GEINTEC 5 (1), 2296-2307. https://doi. org.10.7198/geintec.v5i3.517

Giese E.C. and Vaz P.M. (2015). Bioleaching of primary nickel ore using Acidithiobacillus ferrooxidans LR cells immobilized in glass beads. Orbital 7 (1), 191195. https://doi.org.10.17807/orbital.v7i2.698

Giese E.C. (2017). Biolixiviação: uma avaliação das inovações tecnológicas na biomineração de minerais sulfetados no período de 1991 a 2015. Tecnol. Metal. Mater. Miner. 14 (1), 192-203. https://doi. org. 10.4322/2176-1523.1205

Giese E.C. (2019). Evidences of EPS-iron (III) ions interactions on bioleaching process mini-review: the key to improve performance. Orbital 11 (1), 200-204. https:// doi.org.10.17807/orbital.v11i3.1389

González V., Vignati D.A., Pons M.N., Montarges-Pelletier E., Bojic C. and Giamberini L. (2015). Lanthanide ecotoxicity: first attempt to measure environmental risk for aquatic organisms. Environ Pollut. 199 (1), 139-147. https://doi.org.10.1016/j.envpol.2015.01.020

Gomez J.M., Cantero D. and Webb C. (2000). Immobilisation of Thiobacillus ferrooxidans cells on nickel alloy fibre for ferrous sulfate oxidation. Appl. Microbiol. Biotechnol. 54 (3), 335-340. https://doi.org.10.1007/ s002530000414

Guiza L. and Aristizabal J.D. (2013). Mercury and gold mining in Colombia: A failed state. Univ. Sci. 18 (1), 33-49.

Guo X-L., Deng G., Xu J. and Wang M-X. (2006). Immobilization of Rhodococcus sp. AJ270 in alginate capsules and its application in enantioselective biotransformation of trans-2-methyl-3-phenyl-oxiranecarbonitrile and amide. Enz. Microbial Technol. 39 (1), 1-5. https:// doi.org.10.1016/j.enzmictec.2005.01.044

Gupta P. and Diwan B. (2017). Bacterial Exopolysaccharide mediated heavy metal removal: A Review on biosynthesis, mechanism and remediation strategies. Biotechnol. Rep. 13 (1), 58-71. https://doi. org.10.1016/j.btre.2016.12.006

Hassiba M., Naima A., Yahia K. and Zahra S. (2014). Study of lead adsorption from aqueous solutions on agar beads with EPS produced from Paenibacillus polymyxa. Chem. Eng. Trans. 38 (1), 31-36. https:// doi.org.10.3303/CET1438006 
Hedrich S., Guézennec A-G., Charron M., Schippers A. and Joulian C. (2016). Quantitative monitoring of microbial species during bioleaching of a copper concentrate. Front. Microbiol. 7 (3), 2044. https://doi. org.10.3389/fmicb.2016.02044

Hindersah R., Mulyani O. and Osok R. (2017). Proliferation and exopolysaccharide production of Azotobacter in the presence of mercury. Biodivers. J. 8 (3), 21-26.

Jafari M., Abdollahi H., Shafaei S.Z., Gharabaghi M., Jafari H., Akcil A. and Panda S. (2018). Acidophilic bioleaching: a review on the process and effect of organic-inorganic reagents and materials on its efficiency. Miner. Process. Extr. M. 40 (1), 87-107. https:// doi.org.10.1080/08827508.2018.1481063

Johnson C.A. (1986). The regulation of trace element concentrations in river and estuarine waters contaminated with acid mine drainage: The adsorption of $\mathrm{Cu}$ and $\mathrm{Zn}$ on amorphous Fe oxyhydroxides. Geochim. Cosmochim. Acta 50 (3), 2433-2438. https://doi. org.10.1016/0016-7037(86)90026-8

Joshi P.M. and Juwarkar A.A. (2009). In vivo studies to elucidate the role of extracellular polymeric substances from Azotobacter in immobilization of heavy metals. Environ. Sci. Technol. 43 (1), 5884-5889. https://doi. org.10.1021/es900063b

Kaçar Y., Arpa Ç., Tan S., Denizli A., Genç O. and Arica M.Y. (2002). Biosorption of $\mathrm{Hg}$ (II) and Cd (II) from aqueous solutions comparison of biosorptive capacity of alginate and immobilized live and heat inactivated Phanerochaete chrysosporium. Process Biochem. 37 (1), 601-610. https://doi.org.10.1016/S00329592(01)00248-5

Kawaguti H.Y. and Sato H.H. (2011). Production of isomaltulose obtained by Erwinia sp. cells submitted to different treatments and immobilized in calcium alginate. Food Sci. Technol. 31 (3), 257-263. https:// doi.org.10.1590/S0101-20612011000100039

Khalid S., Han J-I., Hashmi I., Hasnain G. and Arshad M. (2018). Strengthening calcium alginate microspheres using polysulfone and its performance evaluation: Preparation, characterization and application for enhanced biodegradation of chlorpyrifos. Sci. Total Environ. 631-632 (3), 1046-1058. https://doi.org.10.1016/j. scitotenv.2018.03.101

Kleinmann R.L.P., Crerar D.A. and Pacelli R.R. (1981). Biogeochemistry of acid mine drainage and a method to control acid formation. Min. Eng. 33 (1), 300-305.

Kube M., Mohseni A., Fan and Roddick F. (2019). Impact of alginate selection for wastewater treatment by immobilised Chlorella vulgaris. Chem. Eng. J. 358 (1), 1601-1609. https://doi.org.10.1016/j. cej.2018.10.065
Kumar B.M. and Raju S.S. (2008). Biosorption of heavy metals by using free and immobilized cells of Halobacterium cutirubrum. Asian J Microbiol Biotechnol Environ Sci. 10 (3), 97-104.

Kumari S., Mahapatra S. and Das S. (2017). Ca-alginate as a support matrix for $\mathrm{Pb}(\mathrm{II})$ biosorption with immobilized biofilm associated extracellular polymeric substances of Pseudomonas aeruginosa N6P6. Chem. Eng. J. 328 (5), 556-566. https://doi.org.10.1016/j. cej.2017.07.102

Kureel M.M., Geed S.R., Giri B.S., Rai B N. and Singh R.S. (2017). Biodegradation and kinetic study of benzene in bioreactor packed with PUF and alginate beads and immobilized with Bacillus sp. M3. Bioresour. Technol. 242 (3), 92-100. https://doi.org.10.1016/j. biortech.2017.03.167

Lancy E.D. and Tuovinen O.H. (1984). Ferrous ion oxidation by Thiobacillus ferrooxidans inmobilized in calcium alginate. Appl. Microbiol. Biotechnol. 20 (1), 94-99.

Latorre M., Cortés M.P., Travisany S., DiGenova A., Budinich M., Reyes-Jara A., Hördar C., González M., Parada P., Bobadilla-Fazzini R.A., Cambiazo V. and Maass A. (2016). The bioleaching potential of a bacterial consortium. Bioresour. Technol. 218 (3), 659-666. https://doi.org.10.1016/j.biortech.2016.07.012

Lee C.M., Lu C.J, Huang C.Z. and Wang C.C. (1996). Entrapped microbial cell process for treatment of chlorophenolic compounds. In: Immobilized cells: Basics and applications. (R.M.Buitelaar, C. Bucke, J. Tramper, R.H. Wijffels, Eds.). Elsevier, Amsterdam, Netherlands, pp. 739-744.

Lee K.Y. and Mooney D.J. (2012). Alginate: properties and biomedical applications. Prog. Polym. Sci. 37 (3), 106-126. https://doi.org.10.1016\%2Fj.progpolymsci.2011.06.003

Lin C-C. and Lin H-L. (2005). Remediation of soil contaminated with the heavy metal $\left(\mathrm{Cd}^{2+}\right)$. J. Haz. Mat. A122 (1), 7-15. https://doi.org.10.1016/j. jhazmat.2005.02.017

Long Z-E., Huang Y., Cai Z., Cong W. and Ouyang F. (2004). Immobilization of Acidithiobacillus ferrooxidans by a PVA-boric acid method for ferrous sulphate oxidation. Process Biochem. 39 (1), 2129-2133. https:// doi.org.10.1016/j.procbio.2003.11.004

Luk C.H.J., Yip J., Yuen C.W.M., Pang S.K., Lam K.H. and Kan C.W. (2017). Biosorption performance of encapsulated Candida krusei for the removal of copper(II). Scientific Rep. 7 (1), 2159. https://doi.org.10.1038/ s41598-017-02350-7

Maat H.T., Hogendoornb J.A. and Versteeg G.F. (2005). The removal of hydrogen sulfide from gas streams using an aqueous metal sulfate absorbent Part II. The 
regeneration of copper sulfide to copper oxide - an experimental study. Sep. Pur. Technol. 43 (1), 199-213. https://doi.org.10.1016/j.seppur.2004.10.012

Malhotra S., Tankhiwale A.S., Rajvaidya A. and Pandey R.A. (2002). Optimal conditions for bio-oxidation of ferrous ions to ferric ions using Acidithiobacillus ferrooxidans. Bioresour. Technol. 85 (3), 225-234. https:// doi.org.10.1016/S0960-8524(02)00148-7

Martínez P. and Parada P. (2013). Biosigma bioleaching seeds (BBS): A new technology for managing bioleaching microorganisms. Adv. Materials Res. 825 (3), 305-308. https://doi.org.10.4028/www.scientific.net/ AMR.825.305

Martin M.C., López O.V., Ciolino A.E., Morata V.I. and Ninago M.D. (2019). Immobilization of enological pectinase in calcium alginate hydrogels: A potential biocatalyst for winemaking. Biocat. Agric. Biotechnol. 18 (5), 101091. https://doi.org.10.1016/j. bcab.2019.101091

Martínez P.E.B. and Parada P.A.V. (2015). Capsules of viable biomining microorganisms, with alginate and iron ions called biosigma bioleaching seeds (BBS) and their use for inoculation of these microorganisms in bioleaching processes. EUA, Patent Number 20150275324 A1. (C12N1/20; C21B15/00; C12P3/00; C12N11/10; C22B3/18), 20 november 2018. Request US14/433323, 09 oct 2013.

Mishra D., Kim D-J., Ahn J-G. and Rhee Y-H. (2005) Bioleaching - A microbial process of metal recovery: A review. Met. Mat. Int. 11 (3), 249-256. https://doi. org.10.1007/BF03027450

Mishra S.P. (2013). Adsorption of $\mathrm{Cu}$ and $\mathrm{Zn}$ on calcium alginate immobilized Penicillium sp. Ind. J. Chem. Technol. 20 (3), 21-25.

Mitter E.K. and Corso C.R. (2013). Acid dye biodegradation using Saccharomyces cerevisiae immobilized with polyethyleneimine-treated sugarcane bagasse. Water Air Soil Pollut. 224 (1), 1391. https://doi.org.10.1007/ s11270-012-1391-2

Musa D.M., Ujih U.O., Mu'azu A., and Haruna R. (2015). Bioleaching: An important approach for metal refinement-a review. Asian J. Appl. Sci. 3 (1), 82-87.

Nie H., Zhu N., Cao Y., Xu Z. and Wu P. (2015). Immobilization of Acidithiobacillus ferrooxidans on cotton gauze for the bioleaching of waste printed circuit boards. Appl. Biochem. Biotechnol. 177 (1), 675-688. https://doi.org.10.1007/s12010-015-1772-2

Nocelli N., Bogino P.C., Banchio E. and Giordano W. (2016). Roles of extracellular polysaccharides and biofilm formation in heavy metal resistance of Rhizobia. Materials 9 (2), 418-437. https://doi.org.10.3390/ ma9060418
Ozdemir G., Ceyhan N. and Manav E. (2005a). Utilization in alginate beads for $\mathrm{Cu}(\mathrm{II})$ and $\mathrm{Ni}(\mathrm{II})$ adsorption of an exopolysaccharide produced by Chryseomonas luteola TEM05. Word. J. Microbiol. Biotechnol. 21 (2), 163-167. https://doi.org.10.1007/s11274-004-1563-3

Ozdemir G., Ceyhan N., and Manav E. (2005b). Utilization of an exopolysaccharide produced by Chryseomonas luteola TEM05 in alginate beads for adsorption of cadmium and cobalt ions. Bioresour. Technol. 96 (2), 1677-1682. https://doi.org.10.1016/j. biortech.2004.12.031

Park S. and Lee M. (2017). Removal of copper and cadmium in acid mine drainage using Ca-alginate beads as biosorbent. Geosc. J. 21, 373-383. https://doi. org. 10.1007/s12303-016-0050-9

Piotrowska M. and Masek A. (2015). Saccharomyces cerevisiae cell wall components as tools for ochratoxin A decontamination. Toxins 7 (3), 1151-1162. https:// doi.org.10.3390\%2Ftoxins7041151

Rasulov B.A., Yili A. and Aisa H.A. (2013). Biosorption of metal ions by exopolysaccharide produced by Azotobacter chroococcum. J. Environ. Protect. 4 (2), 989-993. https://doi.org.10.4236/jep.2013.49114

Rawlings D.E. (2013). Biomining: theory, microbes and industrial processes. Springer, Verlag Berlin Heidelberg, Germany, 300 pp. https://doi.org.10.1007/9783-662-06111-4

Schippers A. (2004). Biogeochemistry of metal sulfide oxidation in mining environments, sediments, and soils. In: Sulfur biogeochemistry - past and present (J.P. Amend, K.J. Edwards and T.W. Lyons, Eds.). Boulder, Colorado, USA, pp. 49-62.

Syed M., Soreanu G., Falletta P. and Béland M. (2006). Removal of hydrogen sulfide from gas streams using biological processes - A review. Can. Bios. Eng. 48 (1), 2.1-2.14.

Sing S.N. and Tripathi R.D. (2007). Environmental bioremediation technologies. Springer, Verlag Berlin Heidelberg. https://doi.org.10.1007/978-3-540-34793-4

Singer P.C. and Stumm W. (1970). Acidic mine drainage: The rate-determining step. Science 167 (1), 1121-1123, https://doi.org.10.1126/science.167.3921.1121

Sinha A. and Khare S.K. (2012). Mercury bioremediation by mercury accumulating Enterobacter sp. cells and its alginate immobilized application. Biodegradation 23 (1), 25-34. https://doi.org.10.1007/s10532-011-9483-z

Sinha A., Pant K.K. and Khare S.K. (2012). Studies on mercury bioremediation by alginate immobilized mercury tolerant Bacillus cereus cells. Int. Biod. Biodegrad. 71 (1), 1-8. https://doi.org.10.1016/j. ibiod.2011.12.014

Skjåk-Bræk G., Grasdalen H. and Smidsrød O. (1989). Inhomogeneous polysaccharide ionic gels. Carbo- 
hydr. Pol. 10 (1), 31-54. https://doi.org.10.1016/01448617(89)90030-1

Smidsrød O. and Skjåk-Braek G. (1990). Alginate as immobilization matrix for cells. Trends Biotechnol. 8 (1), 71-78. https://doi.org.10.1016/0167-7799(90)90139-O

Tapia P., Santander M., Pávez O., Valderrama L., Guzmán D. and Romero L. (2011). Biosorción de iones cobre con biomasa de algas and orujos deshidratados. Rev. Metal. Madrid 47 (1), 15-28. https://doi.org.10.3989/ revmetalmadrid.0917

Tapia J.M., Muñoz J., González F., Blásquez M.L. and Ballester A. (2016). Sorption of ferrous iron by EPS from the acidophilic bacterium Acidiphilium sp.: A mechanism proposal. Rev. Metal. Madrid 52 (1), e076. https://doi.org.10.3989/revmetalm.076

Tsekova K., Todorova D. and Ganeva S. (2010). Removal of heavy metals from industrial wastewater by free and immobilized cells of Aspergillus niger. Int. Biodeterior. Biodegradation 64 (1), 447-445. https://doi. org.10.1016/j.ibiod.2010.05.003

Usha M.S., Sanjay M.K., Gaddad S.M. and Shivannavar C.T. (2010). Degradation of h-acid by free and immobilized cells of Alcaligenes latus. Braz. J. Microbiol. 41 (2), 931-945. https://doi.org.10.1590/ S1517-83822010000400012

Wilkinson S.C., Goulding K.H. and Robinson P.K. (1989). Mercury accumulation and volatilization in immobilized algal cell systems. Biotechnol. Lett. 11 (2), 861864. https://doi.org.10.1007/BF01026841

Vieira J.D. and Stefenon V.M. (2017). Soil bioremediation in heavy metal contaminated mining areas: a microbiological/biotechnological point of view. J. Adv. Microbiol. 4 (2), 1-10. https://doi.org.10.9734/ JAMB/2017/33782

Vos P., Bucko M., Gemeiner P., Navrátil M., Stivel J., Faas M., Strand B.L., Skjak-Braek G., Morch Y.A., Vikartovská A., Lacik I., Kolláriková G., Orive G., Poncelet D., Pedraz J.L. and Ansorge-Schumacher M.B. (2009). Multiscale requirements for biencapsulation in medicine and biotechnology, Biomaterials 30 (1), 2559-2570. https://doi.org.10.1016/j.biomaterials.2009.01.014
Yantasee W., Fryxell G.E., Addleman R.S., Wiacek R.J., Koonsiripaiboon V., Pattamakomsan K., Sukwarotwat V., Xu J. and Raymond K.N. (2009). Selective removal of lanthanides from natural waters, acidic streams and dialysate. J. Hazard. Mater. 168 (1), 1233-1238. https:// doi.org.10.1016/j.jhazmat.2009.03.004

Yoo I-K., Seong G.H., Chang H.N. and Park J.K. (1996). Encapsulation of Lactobacillus casei cells in liquidcore alginate capsules for lactic acid production. Enz. Microbial Technol. 19 (1), 428-433. https://doi. org.10.1016/S0141-0229(96)00016-6

Yujian W., Xiaojuan Y., Hongyu L. and Wei T. (2006). Immobilization of Acidithiobacillus ferrooxidans with complex of PVA and sodium alginate. Pol. Degrad. Stability 91 (1), 2408-2414. https://doi.org.10.1016/j. polymdegradstab.2006.03.015

Yujian W., Xiaojuan Y., Wei T. and Hongyu L. (2007). High-rate ferrous iron oxidation by immobilized Acidithiobacillus ferrooxidans with complex of PVA and sodium alginate. J. Microbiol. Methods 67 (1), 212-217. https://doi.org.10.1016/j.mimet.2006.07.013

Zeroual Y., Moutaouakkil A. and Blaghen M. (2001). Volatilization of mercury by immobilized bacteria (Klebsiella pneumoniae) in different support by using fluidized bed bioreactor. Cur. Microbiol. 43 (1), 322-327.

Zhang L-H., Meng X-L., Wang Y. and Liu L-D. (2009). Performance of biotrickling filters for hydrogen sulfide removal under starvation and shock loads conditions. J. Zhejiang Univ. Sci. B 10 (2), 595-601. https://doi. org.10.1631/jzus.B0920064

Zhou H-B., Liu X., Qiu G-Z., Liu J-S. and Chen X-H. (2006). Immobilization of Acidithiobacillus ferrooxidans and ferric iron production. Trans. Nonferrous Met. Soc. China. 16 (1), 931-936. https://doi.org.10.1016/ S1003-6326(06)60354-3

Zommere Z. and Nikolajeva V. (2017). Immobilization of bacterial association in alginate beads for bioremediation of oil-contaminated lands. Env. Exp. Biol. 15 (1), 105-111. https://doi.org.10.22364/eeb.15.09

Wang L., Ridgway D., Gu T. and Moo-Young M. (2005). Bioprocessing strategies to improve heterologous protein production in filamentous fungal fermentations. Biotechnol. Adv. 23 (1), 115-129. https://doi. org.10.1016/j.biotechadv.2004.11.001 